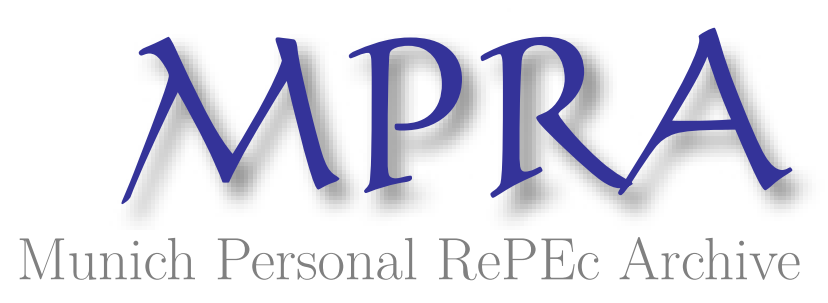

Social security and two-earner households

Kaygusuz, Remzi

Sabanci University

15 July 2011

Online at https://mpra.ub.uni-muenchen.de/32358/

MPRA Paper No. 32358, posted 21 Jul 2011 13:22 UTC 
July 2011

\title{
Social Security and Two-Earner Households
}

\author{
Remzi Kaygusuz*
}

\begin{abstract}
In the past decades, elimination of the pay-as-you-go system in U.S. has been extensively discussed and studied. Such an elimination would also eliminate the intra-cohort redistribution done by the following policies of social security. Due to spousal and survivor's benefit provisions, the system redistributes (mostly) to single-earner married households (not necessarily progressive). Retirement benefits are a concave function of past mean earnings. Hence, the system redistributes from high earners to low earners. Finally, the existence of a cap on social security taxable earnings makes the system regressive. This is the first paper that quantifies redistributive, labor supply, and welfare implications of these policies using a general equilibrium life-cycle model. Agents start out as permanently married or single and with education levels and wage profiles, where the latter depend both on education and gender. The household is the decision maker and decides on the labor supply of its member(s) and saving. The aggregate production function has as inputs capital and labor aggregated by efficiency. Elimination of these policies results in a $6.1 \%$ increase in married female labor force participation rate. The middle-income single-earner married households experience the largest welfare losses whereas the high-income two-earner households together with high-income single households experience the largest welfare gains.
\end{abstract}

JEL Classifications: E62, H31, H55, J12

Key words: Social Security, Two-earner households, Labor Force Participation

* Faculty of Arts and Social Sciences, Sabanci University, Istanbul, Turkey. Email: rkaygusuz@sabanciuniv.edu. I would like to thank to Nezih Guner, Gustavo Ventura, Manolis Galenianos, Edward Green, James Jordan, Neil Wallace, and the participants at Society of Econonomic Dynamics (2007), Midwest Macroeconomics Meetings (2008), DGEM (2008), Public Economic Theory (2010), Income Distribution and Family Conference, University of Iowa, ITAM, Queen Mary University London, Central Bank of Turkey, TOBB-ETU, Koc University, Sabanci University, Central Bank of Turkey. 


\section{Introduction}

U.S. Social Security System is facing a serious financial imbalance over the next 75 years. Projected OASDI tax collections will only be sufficient to finance about $75 \%$ of scheduled annual benefit payments in 2037 through 2084 (Board of Trustees Report 2010). In order to overcome this problem, a number of reform proposals, which include the elimination of the current pay-as-you-go system, have been widely discussed and studied. A major concern with the elimination of the current system is the elimination of intra-cohort redistribution that is due to certain rules of the system. This is the first paper that quantifies welfare and aggregate consequences of eliminating major redistributive rules of social security using a general equilibrium model while keeping the pay-as-you-go feature intact.

Currently, workers face a flat payroll tax rate up to a cap level of earnings. ${ }^{1}$ Monthly benefit entitlement of a retiree, i.e, Primary Insurance Amount (PIA), is a function of average past earnings. The system is generally thought to be progressive since this function replaces a larger fraction of past earnings for lower earners than higher earners. However, spousal and survivor's benefit provisions may break this relation between one's past earnings and retirement income. Current system gives a married retiree the right to collect the higher of own PIA and fifty percent of the spouse's PIA (spousal benefit). For instance, a single-earner married household collects one hundred fifty percent of the PIA of the breadwinner per month upon retirement. ${ }^{2}$ Moreover, a survivor gets the higher of own PIA and one hundred percent of the spouse's PIA (survivor's benefit). Due to these provisions, the system discourages labor force participation of secondary earners and redistributes towards all single-earner married households and to qualifying two-earner households. Since spousal and survivor's benefits increase with past mean earnings of the primary earner in the household, these rules are regressive among the recipients of these benefits. Finally, since workers do not pay payroll taxes for their earnings in excess of the earnings cap, high earners face a lower marginal (payroll) tax rate than low earners. Hence, the earnings cap is a regressive rule

\footnotetext{
${ }^{1}$ In 2010 , the social security tax rate is $12.4 \%$ and the earnings cap is $\$ 106,800$.

${ }^{2}$ Indeed, when the spousal benefit provision was added to social security law in 1939, one of the explicit aims was to encourage traditional bread winner-home maker households. See Carlson (2005) for development of 1939 amendments to social security system.
} 
of social security. Overall and cross-sectional welfare consequences of these four rules are unknown and might have crucial implications for policymaking.

Liebman (2002) is the first paper that attempts to measure the intra-cohort redistribution due to the rules of social security. It is a microsimulation exercise that is able to capture all of the heterogeneity present in the data. However, this study fails to account for the behavioral and general equilibrium implications of counter-factual changes in social security rules. Moreover, it is silent about welfare effects of such changes. As I discuss below, eliminating these rules have significant implications on saving and labor supply decisions of households as well as their welfare.

With these considerations in mind, I build and calibrate a general equilibrium overlapping generations model with capital and heterogenous agents. Agents start out as married or single, and their marital status do not change over the life-cycle. After retirement, each agent faces a gender and age dependent mortality risk. Agents have certain education levels and wage profiles, where the latter depend on agents' education and gender. The household is the decision maker and decides on labor supply of its member(s) and saving. The labor supply decision of a married household is a joint decision and involves a labor market participation decision for the female. The households with two earners incur an additional fixed utility cost, where the costs differ across households. Besides income and capital taxes, workers pay social security taxes. As in the current system, PIA of a retiree is determined by a piecewise-linear concave function. Qualifying married households receive spousal benefit provision, whereas qualifying survivors receive survival benefit provision. The calibrated model economy closely resembles features of the 2000 U.S. economy. The benchmark economy is consistent with observations on gender wage gap, wage premia and married female labor force participation across education groups, and the structure of marital sorting. The structure of taxation closely resembles the income taxes paid in 2000.

I find that eliminating all four policies have significant consequences. In the new steady state, poorer married households experience losses in retirement incomes (as high as 21\%), whereas richer ones experience rises in retirement incomes (as high as 25\%). Households respond to the elimination of these policies by changing their saving and labor supply decisions. Aggregate married female labor force participation rate increases by $6.1 \%$. Changes in output, capital stock, and labor supply are relatively smaller: $0.5 \%, 0.2 \%$, and $0.7 \%$, 
respectively. Aggregate welfare goes up by $0.6 \%$, while more than $74 \%$ of households gain. Married households with relatively low earner females experience welfare losses (as high as $1.1 \%$ ), whereas the ones with high earner females experience welfare gains (as high as $2.2 \%$ ). Contrary to common opinion, the households who are mostly hurt from the elimination of these policies are not the poorest households. The middle-income households where the males are high earners (more than college education) and the females are low earners (less than high school education) experience the largest losses in welfare. On the other hand, single males with more than college education gain about $3.2 \%$, whereas single females with less than high school education lose about $1.1 \%$ in welfare.

Eliminating spousal and survivor's benefits alone increases female labor force participation by $5.2 \%$ as opportunity cost of staying out of the market increases. Single-earner married households, and the two-earner households where females have significantly lower earnings than males experience losses in retirement incomes (as high as 23.6\%). As a result a significant number of females in these households start participating in the labor market (the rise is as high as 11.2\%). Such households incur welfare losses (as high as 1.1\%), whereas through the general equilibrium channel the households who don't collect these benefits experience sizeable welfare gains (as high as 1.7\%).

When progressivity of benefit calculation alone is eliminated, the biggest winners are not the richest households. The elimination of progressivity increases (decreases) benefits of high earners (low earners). Since spousal and survivor's benefits are proportional to the benefits of the primary earner in the household, when the benefits of the primary earner increases, value of spousal and survivor's benefits increases at the same rate. As a result, the elimination of progressivity of benefit calculation benefits mostly the households with very high earning husbands (more than college education) and very low earning wives (less than high school education). Welfare of these households increase by about $2 \%$. On the other hand, when progressivity and spousal\&survivor's benefits are eliminated together, richest married households experience the largest welfare gains of $2.1 \%$, whereas the poorer ones experience a welfare loss of $1 \%$.

Elimination of the earnings cap mostly affects households with high earning members. Due to a higher marginal tax rate, married male workers with more than college education decrease their hours on average by $3 \%$, whereas their wives, who are workers, increase their 
hours by about $1 \%$ (intra-household substitution of labor). Such households experience welfare losses (as high as $0.5 \%$ ).

Related Literature - This paper is related to two strands of literature. First, it builds on papers that analyze aggregate and cross-sectional implications of various reforms to the current pay-as-you-go social security system. Recent contributors include Auerbach and Kotlikoff (1987), İmrohoroğlu, İmrohoroğlu and Joines (1995), Kotlikoff, Smetters and Walliser (1998a), Huggett and Ventura (1999), Conesa and Kruger (1999), Fuster (1999), Storesletten, Telmer and Yaron (1999), Nishiyama and Smetters (2007), Gustman and Steinmeier (2004), Fuster, İmrohoroğlu and İmrohoroğlu (2007), and Huggett and Parra (2010). Second, it is related to papers that analyze macroeconomic implications of the participation (extensive) margin. Cho and Rogerson (1988), Cho and Cooley (1994), Mulligan (2001) and Chang and Kim (2006), among others, are examples of the papers in this group. As Rogerson and Wallenius (2009), Kaygusuz (2010), Guner, Kaygusuz and Ventura (forthcoming), Sanchez-Martin and Marcos (2010) and this paper differs from the others by analyzing the role of the extensive margin for public policy.

Recently, Nishiyama (2010) studies implications of eliminating spousal and survivor's benefit provisions using a general equilibrium model with uninsurable wage shocks. Main differences between this paper and Nishiyama (2010) are: i) it does not model female labor force participation explicitly (he assumes all agents are workers), ii) it does not study implications of progressivity of benefit calculations and earnings cap and hence does not evaluate all redistributive aspects of social security, iii) it only considers married households and therefore overestimates the general equilibrium consequences of eliminating the provisions. Blau (1997) also investigates the effects of the spousal benefit provision on labor force participation of married women. ${ }^{3} \quad$ In order to overcome estimation problems, he assumes away households' saving decisions and labor supply decisions along hours margin, the progressive calculation of benefits and general equilibrium implications of eliminating the provision.

Rest of the paper is organized as follows. Section 2 details specifics of the model. Section 3 describes the parameterization of the benchmark economy. Section 4 has a detailed description of the reforms that I study together with the findings. Section 5 concludes.

\footnotetext{
3 See also Gustman and Steinmeier (2004), Blau (1998), and Blau(1998).
} 


\section{A Life-Cycle Model with Two-Earner Households}

In this section I lay out the details of a stationary general equilibrium life-cycle model populated with single and married households.

\section{Demographics}

The economy is populated by overlapping generations that consists of a continuum of males and a continuum of females. Every period a new generation of individuals is born. The population growth rate is given with $n$. Agents in this economy live at most $J$ periods. They begin life as workers and retire after the mandatory retirement age $j_{R} \cdot{ }^{4} \quad$ Starting with the last period of working life, an agent faces a positive mortality risk at the end of each period. In particular a person with gender $i$, with $i \in\{m, f\}$, faces a survival probability of $\rho_{i j}$ from age $j$ to age $j+1$. Each agent enters economic life as married or single. I assume that a constant fraction $\phi$ of the newborns are married and the rest are single. There is no divorce or marriage over the life-cycle. Note that, since the survival probability is gender dependent, spouses can possibly die at different ages. Moreover, due to the assumption on the values of the survival probability $\left(\rho_{i j}=1\right.$ for $j<j_{R}$ ), a survivor also is a retiree.

\section{Productive Heterogeneity}

Workers differ by their market productivity levels. The productivity of a worker, $e_{i}(z, j)$, depends on the agent's intrinsic skill type $z$, age $j$, and gender $i$. Skill type $z$ comes from a finite set $Z=\left\{z_{1}, z_{2}, \ldots\right\}$. I assume that each agent is born with a particular skill type that does not change over the life-cycle. Moreover, there is no uncertainty about a worker's future productivity.

When $z$ is the skill type of the wife and $\tilde{z}$ is the skill type of the husband, $M(z, \tilde{z})$ denotes the distribution married households by skill types of the spouses. Similarly, $S_{i}(z)$ denotes the distribution of gender- $i$ single households by skill type. Finally, let $\Omega(z)$ and $\Psi(z)$ denote the distributions of males and females by their types, respectively. ${ }^{5}$

\section{Preferences}

In this economy agents value consumption and dislike labor. The utility function for a

\footnotetext{
${ }^{4}$ Retirement in this paper is the age at which the agents start collecting retirement income. Agents can always choose not to work at, or before age $j_{R}$.

${ }^{5}$ As can be seen from the choice of the notation, I assume that these skill distributions are age invariant.
} 
single person is given with

$$
U^{S}(c, l)=\ln (c)-\theta \frac{l^{1+\frac{1}{\gamma}}}{1+\frac{1}{\gamma}},
$$

where $c$ is consumption, $l$ is labor, $\gamma$ is the Frisch elasticity of labor supply, and $\theta>0$ is taste parameter for labor. On the other hand, a married household's utility function is

$$
U^{M}\left(c, l_{m}, l_{f}, q\right)=2 \ln (c)-\theta \frac{l_{m}^{1+\frac{1}{\gamma}}}{1+\frac{1}{\gamma}}-\theta \frac{l_{f}^{1+\frac{1}{\gamma}}}{1+\frac{1}{\gamma}}-\chi\left(l_{f}\right) q
$$

$c$ is consumption, and $l_{i}, i \in\{m, f\}$, is labor supply. $q$ stands for per period utility cost of joint-work. $\chi\left(l_{f}\right)$ is an indicator function that takes a value of 1 if the female supplies a positive amount of labor. I assume that husbands who are not retired always work, but wives may choose to stay out of the labor force. Following Cho and Rogerson (1988), I assume that if a wife participates in the labor market then her household incurs a utility cost of $q \in R_{+}{ }^{6}$ The household draws its utility cost at age 1 from a distribution $\Phi()$ that depends on the skill of the husband. Finally, I assume that $q$ is constant over the life-cycle.

\section{Income}

Labor earnings, capital income, and retirement benefits are the sources of income. The agents participate in a competitive labor market where $w$ is the wage rate per efficiency unit of labor. Households can save in the form of a risk-free asset and earn a competitive rental rate $r$. Moreover, I assume that they are born with no assets and are not allowed to borrow. Asset holdings of a deceased household are not rebated back to the agents who are alive (i.e., no bequests). I focus on a steady state equilibrium at which $w$ and $r$ are constant over time.

A $j$-year old married household $\left(j \leq j_{R}\right)$ earns $e_{f}(z, j) l_{f} w+e_{m}(\tilde{z}, j) l_{m} w$ if the spouses work $l_{f}$ and $l_{m}$ hours in the market. Moreover, if the household's asset holdings is $a$ units, then the total household income is $e_{f}(z, j) l_{f} w+e_{m}(\tilde{z}, j) l_{m} w+r a$. Similarly, income of a $j$-year old single agent is the sum of labor earnings, $e_{i}(z, j) l_{i} w$, and interest income, $r a$.

Income of a retired household is the sum of retirement benefit payments and interest income. Below, I describe the social security system in more detail.

\footnotetext{
6 The utility cost can be interpreted as utility loss due to inconvenience for scheduling and/or less family time with children.
} 


\section{Social Security}

There is a pay-as-you-go social security system that taxes labor earnings and uses all of the proceeds to pay for the retirement benefits.

Taxable earnings for social security purposes consists only of labor earnings up to $E_{\max }>$ 0. For earnings below this cap, a worker faces a proportional social security tax rate $\tau^{p}$. The social security tax payment of a worker is given with

$$
T^{p}\left(e_{i}(z, j) l_{i} w\right)=\tau^{p} \min \left\{e_{i}(z, j) l_{i} w, E_{\max }\right\} .
$$

Henceforth, I will refer to $\min \left\{e_{i}(z, j) l_{i} w, E_{\max }\right\}$ as social security taxable earnings of an agent.

The benefit that an agent is entitled to, $B\left(\bar{e}_{i}\right)$, depends on the average of her/his past social security taxable labor earnings, $\bar{e}_{i}$.

$$
B\left(\bar{e}_{i}\right)= \begin{cases}\xi_{1} \bar{e}_{i} & \text { if } \bar{e}_{i} \leq \kappa_{1} \\ \xi_{1} \kappa_{1}+\xi_{2}\left(\bar{e}_{i}-\kappa_{1}\right) & \text { if } \kappa_{2} \geq \bar{e}_{i} \geq \kappa_{1} \\ \xi_{1} \kappa_{1}+\xi_{2}\left(\kappa_{2}-\kappa_{1}\right)+\xi_{3}\left(\bar{e}_{i}-\kappa_{2}\right) & \text { if } \bar{e}_{i} \geq \kappa_{2}\end{cases}
$$

$\xi_{1}, \xi_{2}$ and $\xi_{3}$ are all between 0 and 1. This particular functional form is the one that is used by the the current social security system. ${ }^{7} \quad$ The past mean earnings of a retiree is calculated as follows.

$$
\bar{e}_{i}=\sum_{j=1}^{j_{R}} \min \left\{e_{i}(z, j) l_{i} w, E_{\max }\right\} / j_{R}
$$

A single household collects her/his entitlement as the social security benefit payment. On the other hand, a married household is treated differently. In principle the household can receive a retirement benefit that is different than the sum of the entitlements of the spouses. The system gives a married person the right to collect the higher of own benefit entitlement and half of the spouse's entitlement. If the person collects the latter she/he is said to collect the spousal benefit. The total benefit payments that the married household receives is given as

$$
H\left(\bar{e}_{f}, \bar{e}_{m}\right)=\max \left\{B\left(\bar{e}_{m}\right)+B\left(\bar{e}_{f}\right), B\left(\bar{e}_{m}\right)+\frac{1}{2} B\left(\bar{e}_{m}\right), B\left(\bar{e}_{f}\right)+\frac{1}{2} B\left(\bar{e}_{f}\right)\right\} .
$$

\footnotetext{
${ }^{7}$ See http://www.ssa.gov/policy/docs/statcomps/supplement/2000/apnd.pdf for details.
} 
A survivor also can collect a retirement benefit that is different than his/her entitlement. The system gives a survivor the right to collect the higher of his/her entitlement and the full amount of the deceased spouse's entitlement. If the agent collects the latter she/he is said to collect the survivor's benefit. The total benefit collection of the survivor can be summarized as

$$
D\left(\bar{e}_{f}, \bar{e}_{m}\right)=\max \left\{B\left(\bar{e}_{m}\right), B\left(\bar{e}_{f}\right)\right\}
$$

\section{Income Taxation}

Households pay income tax and capital income tax. Income tax that a household pays depends on the household's taxable income and marital status. The taxable income is sum of the labor earnings and the capital income. For simplicity, I assume that benefit payments are exempt from income taxation. Income tax functions for married and single households are denoted by $T^{M}($.$) and T^{S}($.$) , respectively.$

In this economy capital income is subject to double taxation. ${ }^{8}$ Besides income taxes, households pay an additional tax for their capital incomes at a proportional rate $\tau^{k}$.

\section{Technology}

There is a single representative firm in the economy which hires capital and labor. Let $K$ denote the aggregate capital and $L$ denote the aggregate labor in efficiency units. The production technology of the firm is

$$
Y=K^{\alpha} L^{1-\alpha}
$$

where $\alpha \in(0,1)$ is the output share of capital. The capital depreciates at a constant rate $\delta \in(0,1)$.

\subsection{Households' Decision Problem}

In this section I describe the problem of the households in the economy. Worker households choose asset holdings and labor supply of the members, whereas retirees only choose the asset holdings. I present the problems of households in a recursive way as follows.

\section{Single Households}

\footnotetext{
8 Additional capital income taxation exists in order to capture the corporate income taxes paid.
} 
Consider the problem of a $j$-year old, gender- $i$, single worker $\left(j \leq j_{R}\right)$. The agent has a skill type $z$ and $a$ units of the asset at the beginning of the current period. Finally, the household observes his/her past mean earnings, $\bar{e}$, before making any decisions. ${ }^{9} \quad$ The household chooses consumption, $c$, labor supply, $l$, and future asset holdings, $a^{\prime}$, by solving the following problem.

$$
V_{i j}^{S}(z, a, \bar{e})=\max _{a^{\prime} \geq 0, l \in[0,1]} U^{S}(c, l)+\beta \rho_{i j} V_{i j+1}^{S}\left(z, a^{\prime}, \bar{e}^{\prime}\right)
$$

subject to

$$
\begin{gathered}
c+a^{\prime}=e_{i}(z, j) w l+(1+r) a-T^{p}\left(e_{i}(z, j) w l\right)-T^{S}\left(e_{i}(z, j) w l+r a\right)-\tau^{k} r a \\
\bar{e}^{\prime}=\frac{(j-1) \bar{e}+\min \left\{e_{i}(z, j) l w, E_{\max }\right\}}{j},
\end{gathered}
$$

where $\beta>0$ is the discount factor. Recall that the survival probability, $\rho_{i j}$, takes values less than 1 for $j \geq j_{R}$. Finally, the last equation describes the law of motion for past mean social security taxable earnings.

The problem of a single retired household $\left(j>j_{R}\right)$ with the same characteristics is given as

$$
V_{i j}^{S}(z, a, \bar{e})=\max _{a^{\prime} \geq 0} U^{S}(c, 0)+\beta \rho_{i j} V_{i j+1}^{S}\left(z, a^{\prime}, \bar{e}\right)
$$

subject to

$$
c+a^{\prime}=(1+r) a+B(\bar{e})-T^{S}(r a)-\tau^{k} r a .
$$

As can be seen from the statement of the problem, $\bar{e}$ for a retiree does not change. It only changes for workers.

\section{Married Households}

Consider the problem of a $j$-year old married household with $j \leq j_{R}$. The wife has a skill type $z$, and the husband has a skill type $\tilde{z}$. The household holds $a$ units of the asset. Recall that $q$ denotes the utility cost of joint work for the household. Before taking any decisions on current consumption $(c)$, labor supply of the husband $\left(l_{m}\right)$, labor supply of the wife $\left(l_{f}\right)$, and future asset holdings $\left(a^{\prime}\right)$, the household observes the past mean earnings of

\footnotetext{
${ }^{9}$ One should note that a new born begins life with zero asset holdings and zero past mean earnings.
} 
the husband and the wife $\left(\bar{e}_{m}\right.$ and $\left.\bar{e}_{f}\right)$. The problem of the household can be written as

$$
\begin{aligned}
V_{j}^{M}\left(z, \tilde{z}, q, a, \bar{e}_{m}, \bar{e}_{f}\right) & =\max _{a^{\prime} \geq 0, l_{f}, l_{m} \in[0,1]} U^{M}\left(c, l_{m}, l_{f}, q\right)+\beta\left[\rho_{m j} \rho_{f j} V_{j+1}^{M}\left(z, \tilde{z}, q, a^{\prime}, \bar{e}_{m}^{\prime}, \bar{e}_{f}^{\prime}\right)\right. \\
& +\rho_{m j}\left(1-\rho_{f j}\right) S V R_{m j+1}\left(\tilde{z}, q, a^{\prime}, \bar{e}_{m}^{\prime}, \bar{e}_{f}^{\prime}\right) \\
& \left.+\rho_{f j}\left(1-\rho_{m j}\right) S V R_{f j+1}\left(z, q, a^{\prime}, \bar{e}_{m}^{\prime}, \bar{e}_{f}^{\prime}\right)\right]
\end{aligned}
$$

subject to

$$
\begin{gathered}
c+a^{\prime}=e_{m}(\tilde{z}, j) w l_{m}+e_{f}(z, j) w l_{f}+(1+r) a-T^{p}\left(e_{m}(\tilde{z}, j) w l_{m}\right) \\
-T^{p}\left(e_{f}(z, j) w l_{f}\right)-T^{M}\left(e_{m}(\tilde{z}, j) w l_{m}+e_{f}(z, j) w l_{f}+r a\right)-\tau^{k} r a, \\
\bar{e}_{i}^{\prime}=\frac{(j-1) \bar{e}_{i}+\min \left\{e_{i}(z, j) l w, E_{\max }\right\}}{j}, i \in\{m, f\} .
\end{gathered}
$$

$S V R_{i j}()$ denotes the value function for a $j$-year old survivor of gender $i$. The husband becomes a survivor with probability $\rho_{m j}\left(1-\rho_{f j}\right)$, whereas the wife becomes one with probability $\rho_{f j}\left(1-\rho_{m j}\right)$. The last equation describes the law of motion for past mean social security taxable earnings of each spouse.

Next, consider the problem of a $j$-year old retired couple. Only choice variable for the household is the asset holdings for future.

$$
\begin{aligned}
V_{j}^{M}\left(z, \tilde{z}, q, a, \bar{e}_{m}, \bar{e}_{f}\right) & =\max _{a^{\prime} \geq 0} U^{M}(c, 0,0, q)+\beta\left[\rho_{m j} \rho_{f j} V_{j+1}^{M}\left(z, \tilde{z}, q, a^{\prime}, \bar{e}_{m}, \bar{e}_{f}\right)\right. \\
& +\rho_{m j}\left(1-\rho_{f j}\right) S V R_{m j+1}\left(\tilde{z}, q, a^{\prime}, \bar{e}_{m}, \bar{e}_{f}\right) \\
& \left.+\rho_{f j}\left(1-\rho_{m j}\right) S V R_{f j+1}\left(z, q, a^{\prime}, \bar{e}_{m}, \bar{e}_{f}\right)\right]
\end{aligned}
$$

subject to

$$
c+a^{\prime}=(1+r) a-\tau^{k} r a+H\left(\bar{e}_{f}, \bar{e}_{m}\right)-T^{M}(r a),
$$

where $H()$ is the benefit payment that the household receives (equation 5).

\section{Survivors}

Finally consider the problem of a $j$-year old survivor with $a$ units of asset holdings. 


$$
S V R_{i j}\left(z, q, a, \bar{e}_{m}, \bar{e}_{f}\right)=\max _{a^{\prime} \geq 0} U^{S}(c, 0)+\beta \rho_{i j} S V R_{i j}\left(z, q, a^{\prime}, \bar{e}_{m}, \bar{e}_{f}\right)
$$

subject to

$$
c+a^{\prime}=(1+r) a+D\left(\bar{e}_{f}, \bar{e}_{m}\right)-\tau^{k} r a-T^{M}(r a)
$$

where $D\left(\bar{e}_{f}, \bar{e}_{m}\right)$ is the retirement benefit of the survivor.

\section{Parameter Values}

In this section I summarize the calibration strategy and discuss parameter values that I use to simulate the model economies.

\section{Demographics}

The model economy is calibrated to the U.S. economy in 2000. U.S. Census data are used unless stated otherwise. ${ }^{10} \quad$ Length of a period is set to be 10 years. Age 1 in the model corresponds to ages between 25 and 34. Agents live at most 7 periods $(J=7)$ and retire after age $4\left(j_{R}=4\right)$. Since all agents die at the end of final period, the probability of survival to the $8^{\text {th }}$ period is set as $0\left(\rho_{i 7}=0\right)$. Recall that agents in the model face mortality risk only at or after age $j_{R}$. Hence, $\rho_{i j}$ is 1 for all $j<j_{R}$ for $i \in\{m, f\}$. The remaining survival probabilities, which are reported in Table 1, are constructed using data from Social Security Administration's publication. The population rate, $n$, is consistent with the long-run average of U.S. population growth rate (see Table 7). As a result, the fraction of retirees in the model economy at any given date is about $18.9 \%$, whereas it is $19.2 \%$ in the data. ${ }^{11}$ Since 74 percent of people between ages 25 and 64 are married in the data, $\phi$ is chosen to be 0.74 .

\section{Skills and Endowments}

I assume that a skill type is represented by education in the data. Moreover, I assume five skill types corresponding to the educational attainment levels defined in Table 2.

\footnotetext{
${ }^{10}$ Source: Census data tabulated by IPUMS-USA, Minnesota Population Center, University of Minnesota (www.ipums.org).

${ }^{11}$ In particular, $19.2 \%$ of all of the individuals older than 25 years of age are the ones who are older than 65 in the 2000 U.S. data.
} 
Table 1: Survival Probability Values

\begin{tabular}{cc}
\hline \hline Females & Males \\
\hline$\rho_{f 4}=0.818$ & $\rho_{m 4}=0.728$ \\
$\rho_{f 5}=0.592$ & $\rho_{m 5}=0.456$ \\
$\rho_{f 6}=0.206$ & $\rho_{m 6}=0.122$ \\
\hline \hline
\end{tabular}

Table 2: Classification of Skill Types

\begin{tabular}{cc}
\hline \hline Skill Type & Educational Attainment \\
\hline$<\mathrm{hs}$ & less than high school degree \\
$\mathrm{hs}$ & high school diploma \\
$\mathrm{sc}$ & less than 4 years of college education \\
$\mathrm{col}$ & college degree \\
$\mathrm{col}+$ & post college education \\
\hline \hline
\end{tabular}

In order to construct the distributions of households by education, I consider the sample between ages 25 and 64 . First, I find the distribution of married households by education of the spouses (as shown in Table 3). One can observe the well known fact about assortative mating from this table. Spouses in most married households have similar educational attainment levels. ${ }^{12}$ Next, I find the distribution of males by education and the distribution of females by education independent of marital status $(\Omega(z)$ and $\Psi(z))$. Using the following accounting identities, I construct the distribution of gender- $i$ single households by education (reported in Table 4).

$$
\begin{aligned}
& S_{m}(z)=\Omega(z)-\sum_{\tilde{z}} M(\tilde{z}, z) \\
& S_{f}(z)=\Psi(z)-\sum_{\tilde{z}} M(z, \tilde{z})
\end{aligned}
$$

Next, I describe how I calibrate the market productivity levels for each skill type and gender. I consider again the individuals who are older than 25 and younger than 64 . I exclude those who are not full-time workers or are self-employed or are unpaid workers or

12 The level of marital sorting by education has been quite high and constant from 1940 until 1980s, but has increased since then. See Mare and Schwartz (2005) for changes in assortative mating by education from 1940 to 2003. 
Table 3: Distribution of Married Households by Education

\begin{tabular}{ccccccc}
\hline & \multicolumn{5}{c}{ Female } & \\
\cline { 3 - 7 } Male & $<\mathrm{hs}$ & $\mathrm{hs}$ & $\mathrm{sc}$ & $\mathrm{col}$ & $\mathrm{col}+$ & Total \\
\cline { 1 - 5 }$<\mathrm{hs}$ & 6.93 & 4.26 & 2.33 & 0.39 & 0.17 & 14.09 \\
$\mathrm{hs}$ & 3.27 & 13.49 & 7.32 & 1.82 & 0.65 & 26.54 \\
$\mathrm{sc}$ & 1.8 & 7.47 & 13.61 & 4.3 & 1.52 & 28.71 \\
$\mathrm{col}$ & 0.39 & 2.35 & 5.73 & 7.52 & 2.56 & 18.55 \\
$\mathrm{col}+$ & 0.17 & 0.87 & 2.57 & 4.33 & 4.17 & 12.11 \\
& & & & & & \\
Total & 12.56 & 28.44 & 31.56 & 18.36 & 9.07 & 100 \\
\hline \hline
\end{tabular}

Table 4: Distribution of Single Households by Education

\begin{tabular}{ccc}
\hline \hline & Males & Females \\
$<\mathrm{hs}$ & 15.24 & 16.60 \\
$\mathrm{hs}$ & 26.69 & 26.48 \\
$\mathrm{sc}$ & 29.52 & 31.64 \\
$\mathrm{col}$ & 18.70 & 15.44 \\
$\mathrm{col}+$ & 9.84 & 9.88 \\
\hline \hline
\end{tabular}

earn less than half of the minimum wage per hour. ${ }^{13}$ I divide the sample into subgroups by age, gender and skill type of individuals. First, I find average weekly wages by dividing total annual wage and salary income to total weeks worked for each subgroup. Then, I normalize them with the mean weekly wage for the entire sample to find the relative market productivity levels. Table 5 reports these productivity values.

Two features of this table are worth noting. First, as documented in Olivetti (2006), age-earning profiles for females are much flatter than the ones for males. Second, as Eckstein and Nagypál (2004) document, there are significant differences between earnings of people with post-college education and college education.

\section{Production Technology}

There are 2 parameters to be determined on the production side of the model. I set the capital share $\alpha$ to be 0.343 and the depreciation rate $\delta$ to be 0.432 (annualized value is 0.055 ) (see Table 7). These values are consistent with a notion of capital that includes fixed private capital, land, inventories, and consumer durables. Altogether, this implies an

\footnotetext{
13 These restrictions are in line with the ones in Katz and Murphy (1992).
} 
Table 5: Productivity Values by Types, by Gender

\begin{tabular}{|c|c|c|c|c|c|c|c|c|c|c|}
\hline \multirow[b]{3}{*}{ Age } & \multicolumn{5}{|c|}{ Males } & \multicolumn{5}{|c|}{ Females } \\
\hline & \multicolumn{5}{|c|}{ Skkill } & \multicolumn{5}{|c|}{ Skill } \\
\hline & $<\mathrm{hs}$ & hs & $\mathrm{sc}$ & col & $\mathrm{col}+$ & $<\mathrm{hs}$ & hs & $\mathrm{sc}$ & $\mathrm{col}$ & $\mathrm{col+}$ \\
\hline 1 & 0.536 & 0.754 & 0.867 & 1.182 & 1.509 & 0.449 & 0.551 & 0.652 & 0.928 & 1.220 \\
\hline 2 & 0.635 & 0.896 & 1.097 & 1.550 & 1.988 & 0.419 & 0.621 & 0.774 & 1.051 & 1.438 \\
\hline 3 & 0.666 & 0.955 & 1.174 & 1.646 & 2.061 & 0.449 & 0.642 & 0.788 & 1.066 & 1.372 \\
\hline 4 & 0.729 & 0.958 & 1.209 & 1.705 & 2.294 & 0.529 & 0.620 & 0.815 & 1.140 & 1.364 \\
\hline
\end{tabular}

annual capital to output ratio of about $2.93{ }^{14}$

\section{Social Security System}

As described in Equation 3, monthly benefit entitlement in the law is calculated with a progressive formula. As the average indexed monthly earnings (AIME) of a retiree increases, the marginal benefit entitlement decreases. In 2000, first $\$ 531$ of AIME is multiplied with 0.90. If applicable, next $\$ 2671$ of AIME is multiplied with 0.32. Finally, the part of AIME that exceeds $\$ 3202$ is multiplied with 0.15. Accordingly, I set $\xi_{1}=0.90, \xi_{2}=0.32$, and $\xi_{3}=0.15$ (see Equation 3). Next, I multiply the bend points in the law with 12 and then normalize them with mean household income of U.S. in 2000. ${ }^{15}$ For benchmark calculations, I multiply these normalized numbers with the mean household income in the benchmark model to determine the bend points. The values of $\kappa_{1}$ and $\kappa_{2}$ that I use in the benchmark model are reported in Table 7 .

Maximum taxable labor earnings for social security purposes in 2000 is $\$ 76,200$. In line with the previous calibration strategy, I normalize this cap with mean household income for 2000. Again, I multiply this normalized number with the mean household income that comes out of the model in order to parameterize $E_{\max }$. Finally, the social security tax rate, $\tau^{p}=0.098$, is the one that balances the social security budget (see Table 7 ).

\section{Income Tax and Capital Income Tax}

In order to better reflect the actual taxes paid as a function of income, I estimate effective taxes paid as a function of reported income and marital status. The 2000 data from Internal Revenue Service is used for these purposes. For married households, I consider married

\footnotetext{
14 See Guner, Kaygusuz and Ventura (forthcoming) for details.

15 Mean household income in 2000 is $\$ 57,135$ (from Census).
} 
households filing jointly, and for single households, I consider single households legal category.

I follow Guner, Kaygusuz and Ventura (forthcoming) in the estimation of the effective functions. Total income tax paid, total income, total number of returns, and total number of taxable returns are available for certain income brackets. Using this data I find the average tax rate as

$$
\text { average tax rate }=\frac{\left\{\frac{\text { total income tax paid }}{\text { number of taxable returns }}\right\}}{\left\{\frac{\text { total income }}{\text { number of returns }}\right\}} .
$$

I also normalize average incomes with mean household income of 2000. Then, I estimate the relationship between these normalized income levels and average tax rates. This procedure is similar to the one in Gouveia and Strauss (1994). In particular, I estimate the following tax functions for married and single households:

$$
T^{M}(\mathcal{I})=[0.104+0.075 \log (I)] \mathcal{I}
$$

and

$$
T^{S}(\mathcal{I})=[0.154+0.059 \log (\mathcal{I})] \mathcal{I}
$$

where $\mathcal{I}$ is the normalized income. Marginal tax rates derived from these tax functions are shown in Figure 2.

Finally, I estimate the capital income tax rate to proxy the corporate income tax payments. Between 1987 and 2000, corporate income tax revenue was approximately 1.92 percent of GDP. Given my assumption about the production technology, a 9.7 percent capital income tax rate replicates this share.

\section{Preference Parameters}

There are three preference parameters to be set. These are $\theta, \gamma$ and $\beta$. The choice of Frisch elasticity of labor supply, $\gamma$, is based on available estimates. For married women, Blundell \& MaCurdy (1999) reports a range of estimates from 0.5 to 1, for males, MaCurdy (1981) finds a range from 0.10 to 0.40 and Altonji (1986) finds a range from 0 to 0.35 . I assume that $\gamma=0.4$.

Given the values of other parameters, the choice of labor parameter, $\theta$, targets the hours worked per worker in the 2000 U.S. Census data. A worker on average spends about $40.1 \%$ 
of his/her available time for labor. ${ }^{16}$ Finally, the discount factor $\beta$ results in a steady-state capital to output ratio that is consistent with the data (see Table 7).

Following Guner, Kaygusuz, and Ventura (forthcoming), I assume that the utility cost of joint work, $q$, is distributed according to (flexible) gamma distribution with parameters $\lambda_{z}$ and $\mu_{z}$. The pdf of the gamma distribution is given as

$$
q^{\mu_{z}-1} \frac{e^{-\frac{q}{\lambda_{z}}}}{\Gamma\left(\mu_{z}\right) \lambda_{z}^{\mu_{z}}}
$$

where $z$ is the type of the husband, and $\Gamma()$ is the Gamma function.

Using Census data, I calculate the employment-population ratio of married females between ages 25 and 54 for each of the educational categories defined earlier. ${ }^{17}$ Table 6 shows the participation rates of married females by types of households for 2000 U.S. economy. The aggregate labor force participation is $69.3 \%$. The choice of $\lambda_{z}$ and $\mu_{z}$ reproduces the participation rates of women who are married to type- $z$ men as close as possible. For instance, the benchmark values of $\lambda$ and $\mu$ for high school graduate men imply participation rates that are consistent with the ones reported in the second row of Table 6 . As discussed in Guner, Kaygusuz, and Ventura (forthcoming), this calibration strategy allows us to exploit the information contained in the differences in the labor force participation of married females as their own wage differ by education. Hence, we get the slope of the distribution of $q$ as in the data, which might be crucial for the quantitative implications of this paper.

Table 6: Labor Force Participation of Married Women, Census 2000, (\%)

\begin{tabular}{cccccc}
\hline \hline & \multicolumn{5}{c}{ Female } \\
Male & $<$ hs & hs & sc & col & col+ \\
\hline$<$ hs & 41.2 & 62 & 71.5 & 77.4 & 69.2 \\
hs & 49.6 & 67.4 & 77.2 & 83.7 & 85.5 \\
sc & 50.1 & 67.9 & 74.8 & 82.9 & 88.4 \\
col & 49.1 & 63.6 & 68.7 & 73.2 & 83.2 \\
col+ & 43.6 & 57.3 & 62.1 & 63.5 & 78.7 \\
\hline \hline
\end{tabular}

${ }^{16}$ I consider people who are between 25 and 54. On average a person works about 2005 hours annually. I assume that 5000 hours is the total amount of time available for work per year.

17 I consider all individuals who are not in the armed forces. 


\begin{tabular}{cc} 
Table 7 : Parameter Values \\
\hline \hline$\gamma$ & 0.4 \\
$\beta$ & $0.843\left(\beta^{0.1} \tilde{=} 0.983\right)$ \\
$\theta$ & 25.5 \\
$\alpha$ & 0.343 \\
$\delta$ & 0.432 \\
$\phi$ & 0.74 \\
$\kappa_{1}$ & 0.112 of mean income \\
$\kappa_{2}$ & 0.673 of mean income \\
$E_{\max }$ & 1.33 of mean income \\
$\xi_{1}$ & 0.90 \\
$\xi_{2}$ & 0.32 \\
$\xi_{3}$ & 0.15 \\
$\tau^{p}$ & 0.098 \\
$\tau^{k}$ & 0.097 \\
\hline \hline
\end{tabular}

\section{Quantitative Analysis}

I evaluate 5 alternative economies in order to quantify the implications of spousal and survivor's benefit provisions, progressive calculation of benefits, and cap on social security taxable earnings. Note that in all of the alternative economies the pay-as-you-go structure is kept intact.

In Economy I, only spousal and survivor's benefit provisions are absent. In Economy II, only porgressivity of benefit calculation is eliminated. In Economy III, spousal and survivor's benefits and progressive calculation are eliminated at the same time. In Economy IV, only cap on earnings is eliminated, and finally in Economy $\mathrm{V}$, all policies are eliminated.

\subsection{Economy 1: Eliminating the Spousal \& Survivor's Benefits}

In this alternative economy married households are not treated favorably: spousal and survivor's benefit provisions are eliminated. Everyone in the economy receives his/her own entitlement as retirement benefit. The social security tax rate is the one in the benchmark economy $\left(\tau^{p}=9.8 \%\right)$. In order to balance the social security budget the benefit entitlement of each individual is increased by $11 \%$.

Implications of eliminating the provisions on aggregate variables are shown in Table 8. 
In the new steady state, output is $1.1 \%$ larger. Hours per worker for both males and females are almost unaffected. The striking observation is that female labor force participation rate increases by $5.2 \%$ even though the wage rate increases only by $0.3 \%$. The decline in social security incomes of some married individuals results in a $1.8 \%$ rise in capital stock, which is coupled with a $0.8 \%$ rise in aggregate labor in efficiency units.

Table 8: Economy 1 vs. Benchmark, Aggregates

\begin{tabular}{cc}
\hline \hline & \% change \\
Hours per Worker (males) & -0.2 \\
Hours per Worker (females) & -0.3 \\
LFP of married women & 5.2 \\
$Y$ & 1.1 \\
$K$ & 1.8 \\
$L$ & 0.8 \\
$w$ & 0.3 \\
\hline \hline
\end{tabular}

Note: Entries show the percentage change in aggregate variables when spousal \& survivor's benefits are eliminated.

As Table 9 shows, the elimination of the provisions have stronger implications on many types of households. Panel $\mathrm{A}$ in the table shows the percentage change in aggregate retirement benefits by types of married households. ${ }^{18}$ The households with relatively low skilled wives and high skilled husbands experience significant losses in the benefits collected after the provisions are eliminated. Note that this is the group of households for which the female labor force participation rate is low in the benchmark economy. As Panel B shows the participation rate for these females increases as much as $11.2 \%$. After losing the provisions, opportunity cost of staying at home increases for many married females. The cost increases more for those who are married to high skilled men as the spousal and survivor's benefits increase with the wage (skill) of the husband. As a result, a larger fraction of such females become workers and increase their savings to compensate for their losses in their retirement incomes.

${ }^{18}$ A survivor's benefit collection is also reported in this panel. For instance, benefits of a colt type female survivor with a colt type deceased husband are counted among the $(\mathrm{col}+, \mathrm{col}+)$ type married houesholds. 
Table 9: Economy 1 vs. Benchmark, Cross-Sectional Effects

Panel A

$\%$ Change in Benefits
Panel B

$\%$ Change in LFP

\begin{tabular}{|c|c|c|c|c|c|c|c|c|c|c|c|}
\hline \multicolumn{6}{|c|}{ Female } & \multicolumn{6}{|c|}{$\overline{\text { Female }}$} \\
\hline Male & $<\mathrm{hs}$ & hs & $\mathrm{sc}$ & col & $\mathrm{col}+$ & Male & $<\mathrm{hs}$ & hs & $\mathrm{sc}$ & col & col+ \\
\hline$<\mathrm{hs}$ & -0.2 & 3.0 & 6.8 & 6.9 & 5.3 & $<\mathrm{hs}$ & 8.0 & 5.9 & 2.3 & -0.5 & -0.4 \\
\hline hs & -8.0 & -3.1 & 3.9 & 7.8 & 7.4 & hs & 9.4 & 6.5 & 5.0 & 1.1 & -0.2 \\
\hline $\mathrm{sc}$ & -12.4 & -7.6 & -2.3 & 7.6 & 9.7 & $\mathrm{sc}$ & 8.8 & 6.1 & 4.7 & 3.0 & 0.9 \\
\hline $\mathrm{col}$ & -20.8 & -14.8 & -10.9 & -1.7 & 4.6 & $\mathrm{col}$ & 7.6 & 8.4 & 6.5 & 3.9 & 2.5 \\
\hline $\mathrm{col}+$ & -23.6 & -19.6 & -15.3 & -6.5 & 0.2 & $\mathrm{col}+$ & 11.2 & 9.7 & 8.5 & 5.4 & 3.2 \\
\hline
\end{tabular}

Panel C

$\%$ Change in Welfare

\begin{tabular}{ccccccccc}
\hline \hline & \multicolumn{9}{c}{ Female } & \multicolumn{3}{c}{ Singles } \\
Male & $<$ hs & hs & sc & col & col + & & Male & Female \\
\hline$<$ hs & 1.6 & 1.5 & 1.6 & 0.8 & 0.6 & $<$ hs & 1.3 & 1.4 \\
hs & 0.8 & 1.2 & 1.6 & 1.3 & 0.9 & hs & 1.3 & 1.4 \\
$\mathrm{sc}$ & 0.1 & 0.6 & 1.0 & 1.7 & 1.4 & $\mathrm{sc}$ & 1.3 & 1.3 \\
$\mathrm{col}$ & -0.9 & -0.2 & 0.2 & 1.0 & 1.4 & $\mathrm{col}$ & 1.2 & 1.3 \\
$\mathrm{col}+$ & -1.1 & -0.6 & -0.2 & 0.6 & 1.0 & $\mathrm{col}+$ & 1.2 & 1.2 \\
\hline \hline
\end{tabular}

Note: Entries show cross-sectional implications of eliminating the spousal and survivor's benefits.

Panel C reports the steady-state welfare implications of the spousal and survivors' benefits. ${ }^{19}$ The numbers in the panel show the percentage change in per period consumption that is needed to make a household living in the benchmark economy as well-off as in the new economy. Even though the majority of households gain from the elimination of the provisions, some married households incur welfare losses. The reason why there are losers is trivial: some households do not collect the provisions anymore. On the other hand, since the equilibrium benefit payments are larger, there are positive welfare effects on most two-earner married households and all single households. The welfare gains are as high as $1.7 \%$ and the welfare losses are as big as $1.1 \%$. Due to higher retirement incomes, the singles experience

19 In all of the counter-factual excercises I compare steady-states. Computation of transition has been standard in this litetature. Given the heterogeneity in the paper there is a high computational burden of computing the transition. 
about a $1.3 \%$ welfare gain.

These findings suggest that spousal and survivor's benefits have a significant redistributive role together with significant welfare implications. The redistribution is from most two-earner households (the ones with high earning women) and singles to single-earner married households and two-earner households with high earning men and low earning women. Moreover, these provisions discourage a sizeable fraction of married females from labor force participation.

\subsection{Economy 2: Removing the Progressivity of the Benefit Cal- culation}

In the second alternative economy, the progressive benefit calculation formula (Equation 3) is replaced with

$$
B\left(\bar{e}_{i}\right)=0.388 \bar{e}_{i}
$$

The social security tax rate in the benchmark economy is unchanged $\left(\tau^{p}=9.8 \%\right.$ ), and the slope of the new benefit function balances the social security budget. All other features of the social security in the benchmark economy (spousal benefit etc.) are kept intact. Figure 1 illustrates the two benefit functions. All else equal, with the new benefit function, the retirees with relatively low amount of past mean earnings get lower income, whereas the ones with relatively high past mean earnings get higher income.

Table 10 reports the aggregate differences between the benchmark economy and Economy 2. Output declines by about $0.7 \%$, whereas the aggregate capital stock declines by $1.6 \%$. Once again, the equilibrium wage rate does not change much. The female labor force participation rate decreases by $1.1 \%$. As the table shows, aggregate implications of removing progressivity of benefit calculations are not large. However, as I discuss below, such a change has very significant implications for many households.

Panel A in Table 11 shows the percentage change in aggregate benefit collections of married households by skill types. The pattern one gets out of this table is that married households with high skilled men get significantly higher retirement income, whereas the ones with low skilled men and low skilled women get significantly lower retirement income. The latter observation is not unexpected because this exercise eliminates the progressive 
Table 10: Economy 2 vs. Benchmark, Aggregates

\begin{tabular}{cc}
\hline \hline & \% change \\
Hours per Worker (males) & 0.2 \\
Hours per Worker (females) & 0.3 \\
LFP of married women & -1.1 \\
$Y$ & -0.7 \\
$K$ & -1.6 \\
$L$ & -0.2 \\
$w$ & -1.5 \\
\hline \hline
\end{tabular}

Note: Entries show the percentage change in aggregate variables when progressivity of benefit calculation is eliminated.

feature of social security. For households with high skilled husbands and low skilled wives, i.e. the middle income households, the big rise in retirement income might look puzzling. This follows from the fact that most of these households collect the spousal and survivor's benefits. Therefore, the benefit collection of the entire household increases at the rate of the husband's benefit entitlement (which is large due to the elimination of progressivity). This exercise clearly demonstrates the fact that the spousal benefit provision redistributes mostly from two-earner households to single-earner married households. Moreover, as the progressivity of the benefit calculation is reduced we observe more of such redistribution.

A further observation is that the elimination of the progressivity increases the gap between the wives' and husbands' benefit entitlements for households where the husbands are more productive (see Figure 1). As a result, more females are discouraged from labor force participation as the spousal and survivor's benefits become more appealing. Panel B of Table 11 reports the resulting changes in the participation rates of married women.

Finally, Panel C reports the steady state welfare comparison of Economy 2 with the benchmark economy. The first table shows that the elimination of the progressivity of benefit calculation clearly favors the middle income married households. Such households' welfare are up by as high as $2 \%$, whereas the poorest married households experience a $2 \%$ decline in their welfare. Single women with low skills experience a $2.5 \%$ decline in welfare, whereas high skilled single men experience a $1.4 \%$ improvement in their welfare.

This exercise demonstrates that progressive benefit calculation is not so progressive when 
Table 11: Economy 2 vs. Benchmark, Cross-Sectional Effects

\begin{tabular}{|c|c|c|c|c|c|c|c|c|c|c|c|}
\hline \multicolumn{6}{|c|}{$\begin{array}{c}\text { Panel A } \\
\% \text { Change in Benefits }\end{array}$} & \multicolumn{6}{|c|}{$\begin{array}{l}\text { Panel B } \\
\text { \% Change in LFP }\end{array}$} \\
\hline \multicolumn{6}{|c|}{ "Female } & \multicolumn{6}{|c|}{ Female } \\
\hline Male & $<\mathrm{hs}$ & hs & $\mathrm{sc}$ & col & $\mathrm{col}+$ & Male & $<\mathrm{hs}$ & hs & $\mathrm{sc}$ & col & $\mathrm{col}+$ \\
\hline$<\mathrm{hs}$ & -20.7 & -20.9 & -17.7 & -8.8 & 3.7 & $<\mathrm{hs}$ & 0.3 & 0.9 & 2.5 & 2.6 & 4.5 \\
\hline hs & -8.0 & -10.4 & -10.7 & -8.3 & 2.3 & hs & -1.9 & -1.7 & -0.5 & 0.7 & 2.1 \\
\hline $\mathrm{sc}$ & 3.1 & 0.3 & -3.0 & -6.2 & 3.0 & $\mathrm{sc}$ & -1.4 & -1.9 & -1.8 & -0.5 & -0.6 \\
\hline col & 25.2 & 23.8 & 20.6 & 13.4 & 14.8 & col & -1.9 & -1.6 & -2.4 & -1.9 & -1.2 \\
\hline $\mathrm{col}+$ & 36.4 & 36.4 & 36.4 & 31.9 & 29.3 & $\mathrm{col}+$ & -1 & -0.9 & -0.9 & -1.9 & -0.2 \\
\hline
\end{tabular}

Panel C

$\%$ Change in Welfare

\begin{tabular}{|c|c|c|c|c|c|c|c|c|}
\hline \multirow[b]{2}{*}{ Male } & \multicolumn{5}{|c|}{ Female } & & \multicolumn{2}{|c|}{ Singles } \\
\hline & $<\mathrm{hs}$ & hs & $\mathrm{sc}$ & $\mathrm{col}$ & $\mathrm{col}+$ & & Male & Female \\
\hline$<\mathrm{hs}$ & -2 & -1.6 & -1.1 & -0.4 & 0.9 & $<\mathrm{hs}$ & -1.5 & -2.5 \\
\hline hs & -1 & -1.2 & -1.2 & -0.8 & 0.2 & hs & -1 & -1.6 \\
\hline $\mathrm{SC}$ & -0.2 & -0.5 & -0.8 & -0.8 & -0.1 & $\mathrm{sc}$ & -0.6 & -1.3 \\
\hline col & 1.4 & 1.2 & 0.9 & 0.4 & 0.3 & col & 0.5 & -0.6 \\
\hline $\mathrm{col}+$ & 2 & 2 & 1.9 & 1.5 & 1.3 & $\mathrm{col}+$ & 1.4 & 0.2 \\
\hline
\end{tabular}

Note: Entries show cross-sectional implications of eliminating the progressivity of benefit calculation.

the spousal and survivor's benefits are present. The degree of progressivity critically affects the number of spousal and survivor's benefit recipients. The removal of progressivity of benefit calculation hurts poor households, which is expected, however, benefits mostly the middle income single-earner married households. Moreover, the elimination discourages more married women from market participation through the disincentives provided by spousal and survivor's benefits. 


\subsection{Economy 3: Eliminating the Spousal and Survivors' Benefits together with the Progressivity of the Benefit Calculation}

In the new alternative economy, spousal and survivor's benefits are eliminated in conjunction with the progressivity of benefit calculation. The social security tax rate is the one in the benchmark economy $\left(\tau^{p}=9.8 \%\right)$, whereas the benefit function is

$$
B\left(\bar{e}_{i}\right)=0.449 \bar{e}_{i}
$$

where the slope, 0.449 , balances the social security budget. Note that social security system in this economy is more generous than the one in Economy 2.

Table 12 shows the percentage differences in the aggregate variables relative to the benchmark economy. Labor force participation of married women is higher by $6.1 \%$. The hours of male and female workers are slightly lower. A 1.7\% larger capital stock and a $1 \%$ larger labor supply is accompanied with a $1.2 \%$ higher output.

Table 12: Economy 3 vs. Benchmark, Aggregates

\begin{tabular}{cc}
\hline \hline & \% change \\
Hours per Worker (males) & -0.2 \\
Hours per Worker (females) & -0.3 \\
LFP of married women & 6.1 \\
$Y$ & 1.2 \\
$K$ & 1.7 \\
$L$ & 1.0 \\
$w$ & 0.7 \\
\hline \hline
\end{tabular}

Note: Entries show the percentage change in aggregate variables when spousal \& survivor's benefits and progressivity of calculation benefits are eliminated.

Since now the spousal and survivors' benefits also are eliminated, we should expect a redistribution from poorer households to richer households through the elimination of progressivity of benefit calculation. Panels A and C in Table 13 confirm this expectation. Low skilled married households get significantly lower retirement incomes, whereas the high skilled ones get significantly higher retirement incomes. The elimination of spousal and survivor's benefits strengthens the implications of the elimination of the progressivity. This 
follows from the fact that poorer married households are mostly single-earners and therefore are the recipients of the spousal benefit. As a result, female labor force participation increases significantly. As Panel B illustrates, the labor supply response of low skilled females is stronger. Panel $\mathrm{C}$ of the same table shows the welfare implications. In contrast to the previous exercise, among married households the biggest winners are richer ones, whereas the poor married households again incur welfare losses. Note that the biggest winners in the previous exercise, the married households with high skilled husbands and low skilled wives, now experience a welfare loss close to $1 \%$ upon losing spousal and survivor benefits. On the other hand, col+ single males experience the largest welfare gains of $3.1 \%$.

Table 13: Economy 3 vs. Benchmark, Cross Sectional Effects

Panel A

Panel B

$\%$ Change in Benefits \% Change in LFP

\begin{tabular}{|c|c|c|c|c|c|c|c|c|c|c|c|}
\hline \multirow[b]{2}{*}{ Male } & \multicolumn{5}{|c|}{ Female } & \multirow[b]{2}{*}{ Male } & \multicolumn{5}{|c|}{ Female } \\
\hline & $<\mathrm{hs}$ & hs & $\mathrm{sc}$ & col & $\mathrm{col}+$ & & $<\mathrm{hs}$ & hs & $\mathrm{sc}$ & $\mathrm{col}$ & $\mathrm{col}+$ \\
\hline$<\mathrm{hs}$ & -23.3 & -18.3 & -9.9 & -2.4 & 5.7 & $<\mathrm{hs}$ & 10.5 & 9.7 & 5.3 & 2.2 & 3.2 \\
\hline hs & -21.9 & -16.1 & -7.8 & 1.0 & 14.2 & hs & 9.2 & 8.2 & 6.8 & 2.5 & 2 \\
\hline $\mathrm{SC}$ & -17.8 & -11.5 & -7.9 & 4.9 & 14.2 & . & 7.7 & 6.5 & 5.2 & 3.8 & 2.5 \\
\hline $\mathrm{col}$ & -10.1 & -4.6 & -1.5 & 8.2 & 21.1 & col & 5 & 7.7 & 6.3 & 4.2 & 3.4 \\
\hline $\mathrm{col}+$ & -5.8 & -1.7 & 3.1 & 13.1 & 23.5 & $\mathrm{col}+$ & 8.3 & 8.7 & 8.3 & 6 & 4.3 \\
\hline
\end{tabular}

Panel C

$\%$ Change In Welfare

\begin{tabular}{|c|c|c|c|c|c|c|c|c|}
\hline \multirow[b]{2}{*}{ Male } & \multicolumn{5}{|c|}{ Female } & & \multicolumn{2}{|c|}{ Singles } \\
\hline & $<\mathrm{hs}$ & hs & $\mathrm{sc}$ & col & col+ & & Male & Female \\
\hline$<\mathrm{hs}$ & -0.7 & 0.0 & 0.6 & 0.6 & 1.2 & $<\mathrm{hS}$ & -0.2 & -1.3 \\
\hline hs & -1 & -0.1 & 0.7 & 0.9 & 1.3 & hs & 0.4 & -0.3 \\
\hline $\mathrm{sc}$ & -1.1 & -0.5 & 0.2 & 1.2 & 1.6 & $\mathrm{sc}$ & 0.9 & 0.1 \\
\hline $\mathrm{col}$ & -1.1 & -0.3 & 0.1 & 1.1 & 1.8 & col & 2.1 & 0.8 \\
\hline $\mathrm{col}+$ & -0.8 & -0.3 & 0.3 & 1.3 & 2.1 & $\mathrm{col}+$ & 3.1 & 1.7 \\
\hline
\end{tabular}

Note: Entries show cross-sectional implications of eliminating spousal and survivor's benefits and progressivity of benefit calculation. 


\subsection{Economy 4: Eliminating the Cap on Earnings}

The cap on social security taxable earnings is eliminated while all other redistributive policies are kept intact in Economy 4. The social security tax rate is the one in the benchmark economy $\left(\tau^{p}=9.8 \%\right)$. In order to balance the budget, I scale up the benefit entitlements of each agent (given with Equation 3) by 1\%. In contrast to the benchmark economy, the workers who earn in excess of the cap level of earnings now face a higher marginal tax rate, however, in return get a higher retirement benefit. Note that past mean earnings are no longer bounded by the earnings cap, hence, there is no longer a cap on benefit entitlements. ${ }^{20}$

Aggregate differences between the current economy and the benchmark economy are reported in Table 14. The differences in the aggregate variables are not large. One important observation is that the hours of female workers slightly increase and the hours of male workers slightly decrease. This exercise increases the marginal tax rates for very productive workers. Therefore, one expects this group to be affected directly. For this reason, below I discuss the changes in working hours of different individuals instead of the participation rates of females.

Table 14: Economy 4 vs. Benchmark, Aggregates

\begin{tabular}{cc}
\hline \hline & \% change \\
Hours per Worker (males) & -0.2 \\
Hours per Worker (females) & 0.3 \\
LFP of married women & -0.2 \\
$Y$ & -0.6 \\
$K$ & -1.0 \\
$L$ & -0.4 \\
$w$ & -0.4 \\
\hline \hline
\end{tabular}

Note: Entries show the percentage change in aggregate variables when cap on social security taxable earnings is eliminated.

Panel A in Table 15 shows how the labor hours of workers compare to their counterparts in the benchmark economy. As expected, col+ married men who earn above the earnings

${ }^{20} E_{\max }$ in Equation 4 and at all other instances are going to be replaced with infinity. 
cap lower their hours significantly due to a higher marginal tax rate. On average, col+ married men decrease their hours by about 3\%. Moreover, women who are married to colt men increase their hours by about $1 \%$. As seen from the table, single col+ males also decrease their labor hours (1.7\%). Welfare implications, which are small, are shown in Panel B of Table 15. Adverse welfare effects of higher taxes for high earners are dampened by the fact that these agents are receiving higher benefits (recall that the cap on benefits also are eliminated).

Table 15: Economy 4 vs. Benchmark, Cross Sectional Effects

Panel A

$\%$ Change in Hours/Worker

\begin{tabular}{cccccc}
\hline \hline Education of & \multicolumn{2}{c}{ Married } & \multicolumn{3}{c}{ Single } \\
Male & Male & Female & & Male & Female \\
$<$ hs & 0.1 & 0.4 & $<$ hs & 0.1 & 0 \\
hs & -0.1 & 0.2 & hs & -0.1 & 0 \\
sc & 0 & 0 & sc & 0.4 & 0 \\
col & 0 & -0.1 & col & 0 & 0 \\
col+ & -3.0 & 1.0 & col + & -1.7 & 0 \\
\hline \hline
\end{tabular}

Panel B

$\%$ Change In Welfare

\begin{tabular}{|c|c|c|c|c|c|c|c|c|}
\hline \multirow[b]{2}{*}{ Male } & \multicolumn{5}{|c|}{ Female } & & \multicolumn{2}{|c|}{ Singles } \\
\hline & $<\mathrm{hs}$ & hs & $\mathrm{sc}$ & col & col+ & & Male & Female \\
\hline$<\mathrm{hs}$ & 0 & -0.1 & 0.1 & 0.1 & 0.1 & $<\mathrm{hs}$ & 0.2 & 0.2 \\
\hline hs & 0.3 & 0.1 & 0.3 & 0.1 & 0.2 & hs & 0.4 & 0.2 \\
\hline $\mathrm{SC}$ & 0.1 & 0.0 & 0.1 & 0.0 & 0.1 & $\mathrm{sc}$ & 0.0 & 0.2 \\
\hline col & 0.2 & 0.2 & 0.2 & 0.2 & 0.1 & $\mathrm{col}$ & 0.2 & 0.0 \\
\hline $\mathrm{col}+$ & -0.5 & -0.4 & -0.3 & -0.2 & -0.1 & $\mathrm{col}+$ & 0.1 & 0.1 \\
\hline
\end{tabular}

Note: Entries show cross-sectional implications of eliminating cap on social security taxable earnings.

\subsection{Economy 5: Eliminating All}

Finally, I consider an alternative economy where spousal and survivor's benefits, progressive calculation of benefits and earnings cap are eliminated. A comparison of Economy 5 and 
the benchmark economy is going to give us a picture of the redistribution implied by the major policies of the current social security. The social security tax rate is $9.8 \%$ and the benefits are calculated with

$$
B\left(\bar{e}_{i}\right)=0.45 \bar{e}_{i}
$$

Table 16: Economy 5 vs. Benchmark, Aggregates

\begin{tabular}{cc}
\hline \hline & $\%$ change \\
Hours per Worker (males) & -0.5 \\
Hours per Worker (females) & -0.3 \\
LFP of married women & 6.1 \\
$Y$ & 0.5 \\
$K$ & 0.2 \\
$L$ & 0.7 \\
$w$ & 0.1 \\
\hline \hline
\end{tabular}

Note: Entries show the percentage change in aggregate variables when all policies considered are eliminated.

As Table 16 shows, female labor force participation is $6.1 \%$ higher in Economy 5, whereas changes in other aggregate variables are less than $1 \%$. Once again, the change in wage rate is very small.

Table 17 shows the redistribution implied by the four redistributive policies considered in the paper. Panel A shows that poorer married households $(<h s,<h s)$ get significantly lower retirement income, whereas richer households get significantly higher retirement income. Elimination of the spousal and survivor's provisions results in significantly higher married female labor force participation, especially for females with relatively lower levels of education. Overall, these changes have sizable welfare consequences. Aggregate welfare increases by $0.6 \%$, while more than $74 \%$ of households gain. As Panel C reports, middleincome married households experience the largest welfare losses (1.1\%) from the elimination of these policies. Poorer households experience a smaller welfare loss (0.6\%). Previous exercises clearly demonstrate why the middle-income married households are the ones who are most adversely affected. The elimination of earnings cap and spousal and survivor's benefits have larger negative effects on these households relative to the poor ones. On the 
Table 17: Economy 5 vs. Benchmark, Cross Sectional Effects

Panel A

Panel B

$\%$ Change in Benefits

$\%$ Change in LFP

\begin{tabular}{|c|c|c|c|c|c|c|c|c|c|c|c|}
\hline \multirow[b]{2}{*}{ Male } & \multirow[b]{2}{*}{$<\mathrm{hs}$} & \multicolumn{3}{|c|}{ Female } & \multirow[b]{2}{*}{$\mathrm{col}+$} & \multirow[b]{2}{*}{ Male } & \multicolumn{5}{|c|}{ Female } \\
\hline & & hs & $\mathrm{sc}$ & col & & & $<\mathrm{hs}$ & hs & $\mathrm{SC}$ & $\mathrm{col}$ & $\mathrm{col}+$ \\
\hline$<\mathrm{hs}$ & -20.8 & -19.1 & -10.5 & -1.5 & 5.2 & $<\mathrm{hs}$ & 7.1 & 9.0 & 5.2 & 2.3 & 3.3 \\
\hline hs & -22.6 & -15.6 & -5.8 & 2.3 & 12.5 & hs & 9.8 & 7.8 & 7.2 & 2.4 & 2.2 \\
\hline $\mathrm{SC}$ & -16.7 & -13.4 & -9.0 & 0.7 & 11.8 & $\mathrm{sc}$ & 7.8 & 6.1 & 5.5 & 3.4 & 2.4 \\
\hline $\mathrm{col}$ & -9.1 & -4.8 & -0.6 & 9.5 & 17.3 & $\mathrm{col}$ & 4.3 & 7.7 & 6.4 & 4.4 & 3.4 \\
\hline $\mathrm{col}+$ & 0.2 & 5.9 & 10.4 & 19.2 & 25.1 & $\mathrm{col}+$ & 9.6 & 10 & 9.1 & 6.6 & 4.6 \\
\hline
\end{tabular}

Panel C

$\%$ Change In Welfare

\begin{tabular}{|c|c|c|c|c|c|c|c|c|}
\hline \multirow[b]{2}{*}{ Male } & \multicolumn{5}{|c|}{ Female } & & \multicolumn{2}{|c|}{ Singles } \\
\hline & $<\mathrm{hs}$ & hs & $\mathrm{sc}$ & col & $\mathrm{col}+$ & & Male & Female \\
\hline$<\mathrm{hs}$ & -0.6 & 0.0 & 0.8 & 0.9 & 1.5 & $<\mathrm{hs}$ & -0.1 & -1.1 \\
\hline hs & -0.6 & 0.1 & 1.1 & 1.1 & 1.6 & hs & 0.8 & -0.1 \\
\hline $\mathrm{sc}$ & -0.9 & -0.3 & 0.4 & 1.2 & 1.7 & $\mathrm{SC}$ & 1.0 & 0.4 \\
\hline col & -0.8 & 0.0 & 0.5 & 1.5 & 2.2 & col & 2.4 & 0.7 \\
\hline $\mathrm{col}+$ & -1.1 & -0.4 & 0.2 & 1.3 & 2.1 & $\mathrm{col}+$ & 3.2 & 1.8 \\
\hline
\end{tabular}

Note: Entries show cross-sectional implications of eliminating all policies considered.

other hand, high earning married households experience a significant welfare gain (2.1\%). Single rich males experience the largest gains of $3.2 \%$.

\section{Conclusions}

Quantitative consequences of eliminating the pay-as-you-go system in US has been explored extensively in the literature. This is the first that paper studies the quantitative implications of eliminating (intra-cohort) redistributive policies of social security without eliminating the pay-as-you-go feature of the system using a general equilibrium life-cycle model. The findings of the paper have crucial policy implications. Contrary to common perception, the redistribution currently being done by the system is mostly favoring "traditional" 
single-earner American households. This redistribution is significantly hurting many single households and two-earner married households. Moreover, spousal and survivor's benefits discourage labor force participation for many married females.

As future research, current model can be extended to study the implications of eliminating the-pay-as-you-go system on female labor supply. In Guner, Kaygusuz, and Ventura (forthcoming), we find that changes in income taxes can have significant effects on female labor force participation. Similarly, the elimination of social security taxes should have significant effects on female labor supply. 


\section{References}

Altonji, J. G., "Intertemporal Substitution in Labor Supply: Evidence from Micro Data," Journal of Political Economy, vol. 94, no.3, (June 1986), S176-S215.

Auerbach, A. J. and L. J. Kotlikoff, "Dynamic Fiscal Policy," Cambridge University Press, Cambridge, 1987.

Blau, D. M., "Social Security and The Labor Supply of Older Married Couples," Labour Economics, vol. 4, no. 4, (December 1997), 373-418.

Blau, D. M., " Labor Force Dynamics of Older Married Couples," Journal of Labor Economics, vol. 16, no. 3, (July 1998), 595-629.

Blundell, R. and T. E. MaCurdy, "Labor Supply: a Review of Alternative Approaches," In Handbook of Labor Economics, vol. 3A, ed. O. A Ashenfelter and D. Card, Amsterdam: North Holland, 1599-1695.

Carlson, A. C, "Making Social Security Reform Family-Friendly," Family Research Council, (February 2005), http://www.frc.org/get.cfm?i=PL05C01.

Chang, Y. and S. Kim. "From Individual to Aggregate Labor Supply: A Quantitative Analysis Based on a Heterogeneous-Agent Macroeconomy," International Economic Review, vol. 47, no.1, (2006), 1-27.

Cho, J.O. and T. F. Cooley, "Employment and Hours Over The Business Cycle," Journal of Economic Dynamics and Control, vol. 18, no.2, (March 1994), 411-432.

Cho, J. and R. Rogerson, "Family Labor Supply and Aggregate Fluctuations," Journal of Monetary Economics, vol. 21, no. 2, (March 1988), 233-245.

Conesa, J. C. and D. Krueger, "Social Security Reform with Heterogeneous Agents," Review of Economic Dynamics, vol.2., no. 4, (July 1999), 757-795.

De Nardi, M., S. İmrohoroğlu and T. J. Sargent, "Projected U.S. Demographics and Social Security," Review of Economic Dynamics, vol.2., no. 3, (July 1999), 575-615.

Eckstein, Z. and E. Nagypál, "The Evolution of U.S. Earnings Inequality: 1961-2002," Federal Reserve Bank of Minneapolis Quarterly Review, vol. 28, no. 2, (December 2004), 10-29.

Eissa, N., "Taxation and The Labor Supply of The Women: The Tax Reform Act of 1986 As A Natural Experiment," NBER Working Paper, \#5023, 1995.

Eissa, N. and H. Hoynes, "Behavioral Responses to Taxes: Lessons from the EITC and Labor Supply," NBER Working Paper, \#11729, 2005. 
Fuster, L., "Is Altruism Important for Understanding the Long-Run Effects of Social Security," Review of Economic Dynamics, vol.2., no. 3, (July 1999), 616-637.

Fuster, L., A. İmrohoroğlu and S. İmrohoroğlu, " A Welfare Analysis of Social Security In a Dynastic Framework," International Economic Review, vol. 44, no.4, (November 2003), 1247-1274.

Framework," The Review of Economic Studies, vol. 74, no. 1, 2007, 113-145.

Gouveia, M. and R. P. Strauss, "Effective Federal Individual Income Tax Functions: An Exploratory Empirical Analysis," National Tax Journal, vol. 40, no. 2, (June, 1994), 317-339.

Guner, N., R. Kaygusuz and G. Ventura, "Taxation, Aggregates and The Household," forthcoming at The Review of Economic Studies.

Gustman, A. L. and T. L. Steinmeier. "How Effective Is Redistribution Under The Social Security Benefit Formula?," Journal of Public Economics, vol. 82, no.1,(October 2001), 1-28.

Gustman, A. L. and T. L. Steinmeier. "Social Security, Pensions and Retirement Behaviour Within The Family," Journal of Applied Econometrics, vol. 19, no.6,(Special Issue 2004), 723-737.

Huang, H., S. İmrohoroğlu and T. J. Sargent , "Two Computations to Fund Social Security," Macroeconomic Dynamics, vol. 1., no. 1, (March 1997), 7-44.

Hubbard, R. G. and K. L. Judd, "Social Security and Individual Welfare: Precautionary Saving, Borrowing Constraints, and The Payroll Tax" The American Economic Review, vol. 77, no. 4, (September 1987), 630-646.

Huggett, M. and J. C. Parra, "How Well Does the U.S. Social Insurance System Provide Social Insurance?," Journal of Political Economy, vol. 118, no. 1, (2010), 76-112.

Huggett, M. and G. Ventura, "On the Distributional Effects of Social Security Reform," Review of Economic Dynamics, vol.2., no. 3, (July 1999), 498-531.

İmrohoroğlu, A. , S. İmrohoroğlu and D. Joines, "A Life Cycle Analysis of Social Security," Economic Theory, vol. 6, no.1, (June 1995), 83-114.

Internal Revenue Service Statistic of Income Division, Individual Income Tax Returns, 2000 .

Kaygusuz, R. "Taxes and Female Labor Supply," Review of Economic Dynamics, vol. 13, no. 4, (October 2010), 725-741. 
Kimmel, J. and T. J. Kniesner, "New Evidence on Labor Supply: Employment Versus Hours Elasticities by Sex and Marital Status," Journal of Monetary Economics, vol. 42, no. 2, (July 1998), 289.301.

Kotlikoff, L. J., K. Smetters and J. Walliser , "Opting Out of Social Security and Adverse Selection," NBER Working Paper, \#6430, 1998a

sivity," The American Economic Review, vol. 88, no. 2, (May 1998b), 137-141.

"Privatizing Social Security in the United

States - Comparing the Options," Review of Economic Dynamics, vol.2., no. 3, (July 1999), 532-574.

Liebman, J. " Redistribution in the Current U.S. Social Security System", in Martin Feldstein and Jeffrey B. Liebman editors, The Distributional Aspects of Social Security and Social Security Reform (Chicago: University of Chicago Press), 2002.

MaCurdy, T. E., "An Empirical Model of Labor Supply in a Life-Cycle Setting," Journal of Political Economy, vol. 89, no. 6, (December 1981), 1059-1085.

Mare, R. D. and C. R. Schwartz, "Trends in Educational Assortative Marriage from 1940 to 2003." Demography, vol. 42, no.4, (November 2005), 621-626.

Sanchez-Martin, A. R. and V. S. Marcos, "Demographic Change, Pension Reform and Redistribution in Spain" Fiscal Studies, vol. 31, no. 3 (2010), 405-452.

McCaffery, E. J., Taxing Women, The University of Chicago Press, Chicago, 1997.

Mulligan, C. B., " Aggregate Implications of Indivisible Labor," Advances in Macroeconomics, vol.1, no.1, (2001).

Nicolaou, C. and R. Stanfield, "Social Security: Out of Step with the Modern Family," Urban Institute, (April 2000), http://www.urban.org/url.cfm?ID=310233.

Nishiyama, S., "The Joint Labor Supply Decision of Married Couples and the Social Security Pension System” manuscript, Georgia State University, September 2010.

Nishiyama, S. and K. Smetters, "Does Social Security Privatization Produce Efficiency Gains?," Quarterly Journal of Economics, vol. 122, no., (November 2007), 1677-1719.

Olivetti, C., "Changes in Women's Aggregate Hours of Work: The Role of Returns to Experience," Review of Economic Dynamics, vol.9 no.4, (October 2006), 557-587.

Rix, S. E. and J. B. Williamson, "Social Security Reform: Implications for Women," Journal of Aging \& Social Policy, vol. 11, no. 4, (Summer 2000), 41-68. 
Rogerson, R. and J. Wallenius, "Micro and Macro Elasticities in a Life Cycle Model with Taxes," Journal of Economic Theory, vol. 144, no. 6, (November 2009), 588-601.

Storesletten, K., C. I. Telmer and A. Yaron, "The Risk Sharing Implications of Alternative Social Security Arrangements," Carnegie-Rochester Conference Series on Public Policy, Elsevier, vol. 50, (June 1999), 213-259. 


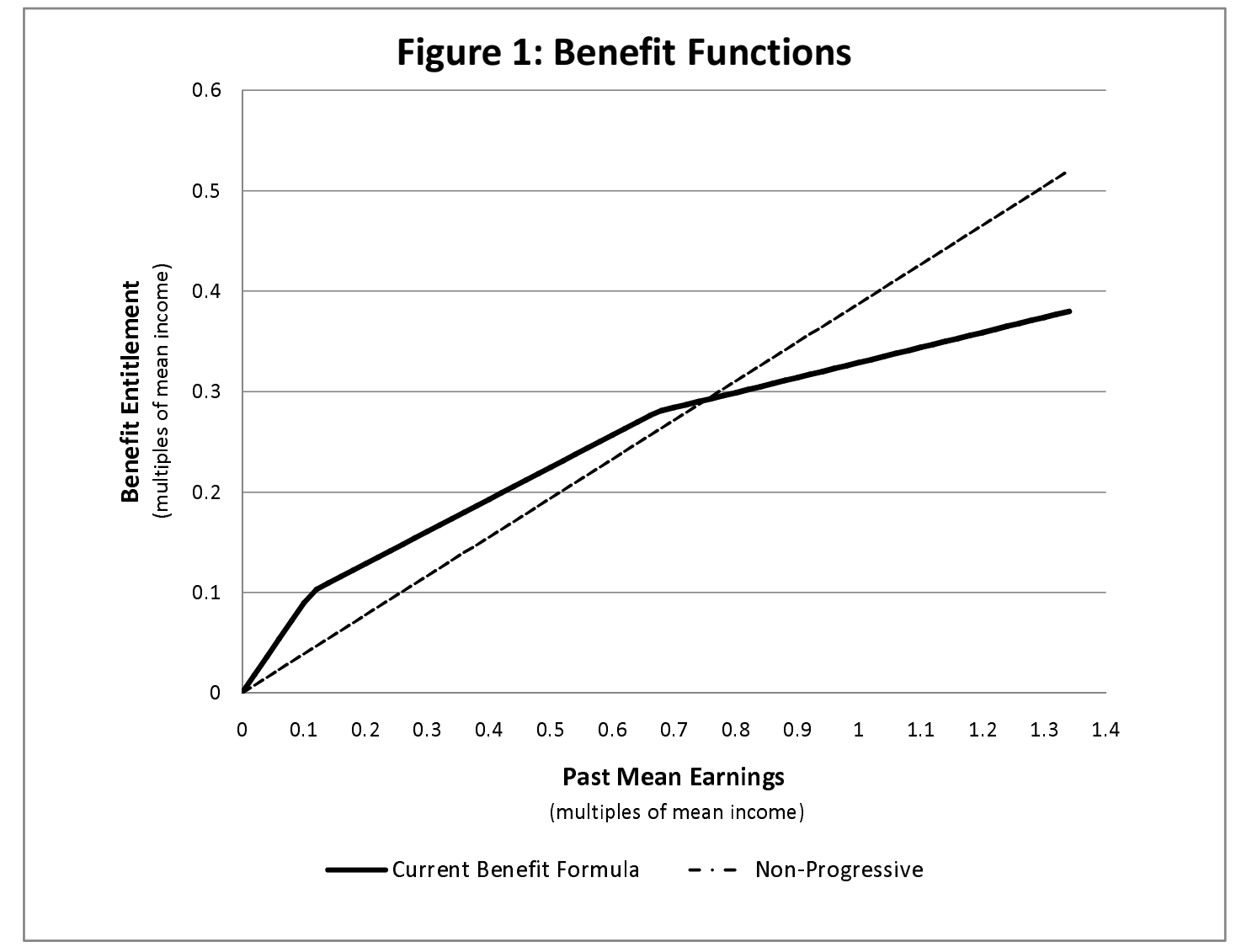




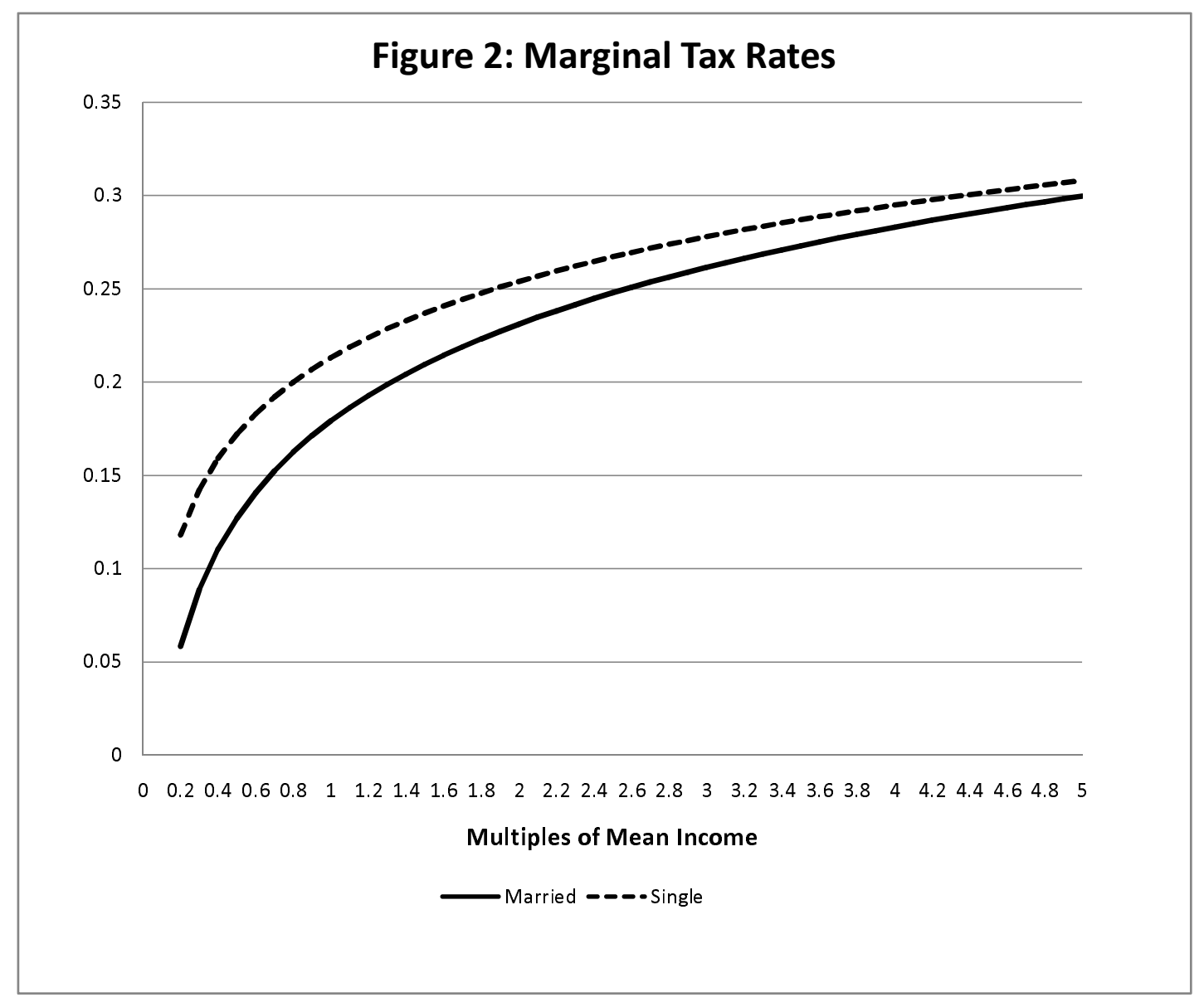

